\title{
Die Verfassung des Dentschen Reichs vom 11. August 1919
}

\section{Ein systematischer Überblick}

\author{
von \\ Dr. Fritz Stier-Somlo \\ ordentlicher Professor des öffentlichen Rechts \\ und der Politik an der Universitut Cöln
}

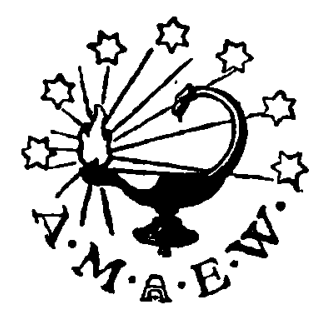

Bonn 1919

A. Marcus \& E. Webers Verlag

(Dr. jur. Albert Ahn) 
Nachdruck verboten.

Alle Rechte, besonders das der Übersetzung in fremde Sprachen, vorbehalten. 
Hern Geheimem Regierungsrat

Professor Dr. jur, et phil. Christian Eckert

dem ersten Rektor der neuerstandenen

Universität Cöln

in herzlicher Freundschaft 
